\title{
The Effect of Transformational Leadership and Knowledge Management on Intellectual Capital and Its Implication on the Performance of State Owned Bank Branch Offices in West Java
}

\author{
Hady Siti Hadijah \\ Student of Doctoral Science Management UNPAD),Lecturer of Office Management Departement Indonesia \\ University of Education; Email: hady.sch@gmail.com \\ Erni Tisnawati Sule \\ Lecturer of Padjadjaran University \\ Yunizar \\ Lecturer of Padjadjaran University \\ Asep Mulyana \\ Lecturer of Padjadjaran University
}

\section{Doi:10.5901/mjss.2015.v6n5s5p97}

\begin{abstract}
The performance of state-owned banks from the aspect of profitability and efficiency is not too bad as indicated by the high ratio average of NIM and ROA and fairly low BOPO. However the low enough BOPO should be alerted because the cost of third-party funds as well as the relatively high operating expenses offset by higher lending rates. Indonesian Banking mainly state-owned banks should improve as it will face the competitive market in which our banks will compete with the big banks, especially banks of Singapore and Malaysia in the ASEAN Economy Community (AEC) by 2020. One of the policies to improve the functioning of global-oriented intermediation is giving high flexibility to the branch office. Potential bank branches can be explored through the enhancement of intellectual capital variables. This increase can be caused by an increase in transformational leadership and knowledge management variables. Intellectual capital is measured through the dimensions of human capital, structural capital and relationship capital. Transformational leadership dimensions are measured through idealized influence, inspirational motivation, intellectual stimulation, and individual consideration. Knowledge management dimensions are measured through socialization, externalization, combination, and internalization. The nature of paper is finalizing the concept before empirical tests and performed with the scope of intensive study at the branch office managers of state-owned banks and theoretically can be concluded that the strengthening of transformational leadership and knowledge management at branch offices to improve intellectual capital is the key in improving the performance of state-owned bank branch offices in West Java.
\end{abstract}

Keywords: Transformational Leadership, Knowledge Management, Intellectual Capital, Bank Performance

\section{Introduction}

State-owned banks is one of the banking institutions that serve as a means of intermediary between the owner of the funds to the user funds. The existence of banking institutions including state-owned banks is a manifestation of the government's role in implementing the mandate of the 1945 Constitution in the welfare of its people.

The performance of state-owned banks are relatively good and lead the domestic market share. This is reflected in the value of its LDR ie $86.7 \%$ are categorized as ideal (85\% -100\%), its highest ROA and ROA its lowest compared with the National Private Banks and Private Banks Foreign (Stats Banking, 2014). Nevertheless BOPO ratio low enough that warrant concern because although the cost of third-party funds as well as other operating expenses is high but high operating expense is offset by the interest rate is too high, as can be seen from the high ratio of NIM.

Our banking should be improve, especially the state-owned banks because they will face the ASEAN Economy Community (AEC) by 2020. National Bank will face a competitive market, competing with the big banks, especially banks 
from Singapore and Malaysia, two countries that have the best in the banking industry ASEAN.

One of the policies to improve the functioning of global-oriented intermediation is giving high flexibility to branch offices as they understand the local potential better. Branch offices are the focus of the assessment is the state-owned bank branch offices located in West Java because of the contribution of industry to GDP in the region is relatively large compared to other provinces (CBS, 2013) that functions as an intermediary bank are more needed.

Attention to the state-owned bank resources should be a priority, not only in tangible resources. Bontis (2000) termed a set of intangible resources such as intellectual capital. Strategic role of intellectual capital into intellectual capital when it is able to create value and performance. But in fact, the existing intellectual capital in state-owned banks have not been optimal.

Factors necessary to maintain and optimize the intellectual capital is a quality leader with its ability to integrate elements of intellectual capital into an advantage. Leaders who are able to increase the intellectual capital of capital, the mindset is starting from seeing employees as an asset and an important part of the future of the company. Such leaders are leaders who implement transformational leadership. Application of transformational leadership in addition to improving performance, is also a construct antasenden (precede) for intellectual capital (are intervening), especially human capital so that further strengthen the role of intellectual capital in improving the performance (Bontis and Fitz-Enz, 2002). So it is clear that the effect of transformational leadership on organizational performance is directly besides also mediated by the intellectual capital (Hadi, and Abdul Wahab Al-Abror, 2014).

Another factor that is needed is knowledge management. High interest in the real sector banks led to the need for human resources with competence in each of the real sector increased rapidly provide opportunities for piracy and transfer of human resources from one bank to another. For this case knowledge management required to maintain and create as much as possible this important human resource.

In this paper, objects covered are branches of banks led by the head of a branch given a better understanding of the potential leaders of local branches, more resources have the sensitivity to the surrounding, and the dynamics of the real sector in the work area. Bank with branches must have a high attention to the resources that exist at present and how these resources are used through giving more attention to the organization.

\subsection{Statement of the Problem}

Do Transformational Leadership and Knowledge Management affect the Intellectual Capital and whether the Intellectual Capital affects the performance of branch office of state-owned banks in West Java.

\subsection{Purpose}

The purpose of this paper is to strengthen the concept of whether the Transformational Leadership and Knowledge Management affect the Intellectual Capital and whether the Intellectual Capital affects on the performance of branch office of state-owned banks in West Java.

\section{Literature Review}

\subsection{Transformational Leadership}

Bass and Riggio (2006) defines transformational leadership as a position of leadership that has the power to give effect to his subordinates with a particular method so that subordinates feel trust, admiration, and respect the leadership that subordinates are motivated and inspired to be able to carry out the task as well as possible.

Dimensions of transformational leadership was initially described by Bass (1990), which explains that transformational leadership is a process of behavior that consists of four dimensions: (1) Effect of Ideal (Idealized influence): transformational leader gives an example and act as a positive role model in behavior, achievement, and commitment to his followers. Leaders provide vision and sense of mission to his people, as well as instilling a sense of pride to his subordinates. (2) Inspirational Motivation: leaders motivate and inspire subordinates to communicate high expectations and challenging work that loud and clear. (3) intellectual stimulation : leader encourages followers to think creatively and innovatively. (4) Individual Consideration : a leader who tends to show his attention to the individual needs of his followers. 


\subsection{Knowledge Management}

Knowledge management is defined as a management function that is responsible for the selection, implementation, and evaluation of knowledge-oriented strategy on the way the organization handles internal and external knowledge organization in order to improve organizational performance. (Ronald Maier, 2007). Knowledge management is implemented in an effort to optimize organizational performance. In line with the above definition of knowledge management is a system or framework that integrates people, processes, and technology to achieve sustainable results by improving organizational performance through learning (Bacerra et.al., 2010).

Further, he said, that knowledge management is a tool to increase the intellectual capital that is an intangible asset, which in turn will ensure tangible assets in the form of financial success in the future (Pasher, 2011). From the definition above, we can see that knowledge management is a series of activities undertaken by the organization continuously to maintain the existing knowledge and creates new knowledge by integrating cutting-edge people, processes, and technology to improve performance.

The process of knowledge creation in the organization is defined as the process of making and strengthen existing knowledge created by individuals and crystallizes knowledge and connect it to the system of organizational knowledge. As for the knowledge creation process consisting of four modes of knowledge conversion (socialization, externalization, combination and internalization) known as SECI models. (Nonaka and Takeuchi, 1995)

\subsection{Intellectual Capital}

Edvinsson and Sullivan (1996) see intellectual capital as knowledge that can be converted into value. Stewart (1997) and Bontis (2000) refers to the intellectual capital as the aggregation of all the knowledge and competence of the employees that enables organizations to achieve competitive advantage. In the intellectual capital there are three elements, namely intellectual capital inherent in human beings, attached to the organization, and those related to external parties, such as the proposed Edvinsson and Sullivan (1996), Sveiby (1997), and Stewart (1997).

Intellectual capital inherent in humans is known as human capital (employee competencies) is the acquisition of knowledge, technology, and innovation by the human resources of the organization in its efforts to achieve the goal. Intellectual capital inherent in the organization known as structural capital (capital organizational or internal structures) is a company's ability to meet the company's routine process to produce optimal business performance. Intellectual capital inherent in the company's relationships with external parties known as the relational capital (customer capital) is a harmonious relationship with the company owned by parties outside the company. These three elements will work if each other are interconnected.

\subsection{Performance}

The performance of the organization is the organization's ability to achieve its goal by using resources efficiently and effectively (Daft, 2000; Hamon, 2003; Verboncu \& Zalman, 2005).

Bank performance as a whole is an achievement bank in operation, either in relation to financial aspects, marketing, collection and distribution of funds. With reference to the banking activity, performance associated with increased added value and optimal ratio between costs and benefits. Banking efficiency is very important in explaining and interpreting the performance of banks also profit from a source pendanaanyang perbankan. (Cocriş \& Andries, 2009; Cocriş \& Chirleşan, 2007; Gruian 2010).

Based on some notion of the performance of the above, it is understood that the bank's performance is the result of the bank reached concerning aspects of the collection and distribution of funds effective, operational efficiency, and growth in customer numbers.

Performance measurement in this study are based on the bank's main task as a financial intermediary that channel funds from the excess funds to those who lack the funds that can be seen from the Loan to Deposit Ratio (LDR), and operational efficiencies that can be seen from the Return on Assets (ROA) and the ratio of operating expenses to operating income (BOPO), as well as growth in the number of customers (Snow \& Hrebiniak, 1983; Segev, 1987; Smith, Guthrie \& Chen, 1989; Parnell \& Wright, 1993; Thomas \& Ramaswamy, 1996; Gimenez, 2000).

LDR is the ratio between the total number of bank loans with funds received by the bank (Lukman, 2009). The lower the ratio is an indication of the lower ability of banks to extend credit. Most practitioners agree that banking safe limit a bank's LDR was about $85 \%-100 \%$.

$\mathrm{ROA}$ is the ratio used to measure the ability of the bank's management in the overall gain. The greater the ROA of 
a bank, the greater the level of profit that the bank achieved and the better the position of the bank in terms of asset utilization. (Lukman, 2009)

BOPO is the ratio between operating expenses and operating income. (Lukman, 2009). BOPO is used to measure the efficiency and ability of banks to carry out operations.

\subsection{Effect of Transformational Leadership and Intellectual Capital}

Selection of the appropriate leadership style in accordance with the external motivation can help the organization and management of intellectual capital to achieve their goals. The results showed that transformational leadership style has a direct impact on the intellectual capital (Nazem, 2013 and Sarlak, 2012). The existence of transformational leadership can be the key to the creation and development of intellectual capital to achieve long-term success of an organization (Sorin, 2012).

\subsection{Effect of Knowledge Management and Intellectual Capital}

Knowledge management is a tool to increase the intellectual capital which in turn guarantees of future financial success (Pasher, 2011) because knowledge management and ensure that relevant knowledge assets can be enhanced and effectively used (Rajesh et. Al., 2011). A knowledge management processes and activities aimed at acquiring, creating, documenting, transfer, and apply knowledge that has an influence on the intellectual capital (Nazem, 2012). Based on the concept and the results of their research can be concluded that in order to increase the intellectual capital effectively and have the added value required the application of management knowledge constantly.

\subsection{Effect of Transformational Leadership and Performance}

Most of the research findings show that leadership behavior was significantly related to organizational performance. Muterera (2012) in his research, conducted in the United States, revealed that both transactional and transformational leadership behavior is positively related to organizational performance. Ejere (2013) and Obiwuru (2011) concluded from his research that the transformational leadership style has a strong positive impact on the performance of the organization, while the transactional leadership style has a weak positive impact on organizational performance. Thus, with regard to the study authors, if the branch office is seen as a small company that given the discretion, the transformational leadership style would be better applied to the branch offices

\subsection{Effect of Knowledge Management and Performance}

Nonaka in his research in 1995 that uses a matrix SECl as the dimensions of knowledge management believes that the success of many companies depends on their ability to create new organizational knowledge through the transformation of tacit and explicit knowledge at three levels, namely individuals, groups and organizations. Knowledge management is a system or framework that can achieve sustainable results by improving organizational performance through learning (Wang, 2011).

Their knowledge management led to the development of new ideas, new products, and also new ways of doing things that will ultimately lead to improvements in organizational performance (Mahapa, 2013). Rasula research results (2012) indicate that knowledge management is a process that transforms individual knowledge into organizational knowledge. Through the process of creation, collect, organize, and utilize knowledge, organizations can improve its performance.

Based on some of the research that has been stated above it can be concluded that knowledge management will be able to improve the performance of an organization. In this research, knowledge management variables measured by the model of Nonaka SECl. Meanwhile, the performance of bank branches will be measured based on the bank's role as an intermediary function (which channeled funds from the party fund surplus to those in need of funds) is the performance of funding and disbursement of funds, operational, and customer satisfaction. The bank performance measurement in accordance with the indicators used by Ranjani (2011) in his research on the performance of the bank, where customer satisfaction is measured through growth in customer numbers. 


\subsection{Effect of Intellectual Capital and Performance}

Based on the results of previous studies that the three dimensions of intellectual capital (human, structural, and customer I relational) are interlinked, will have a positive influence on organizational performance. Highly competent employees (human capital) will be able to understand customer needs, and they will develop customer capital to maintain their loyalty, and both human and customer capital will affect the structural capital, which in turn, has a positive influence on business performance (Nazari, 2010 ). Furthermore, intellectual capital can be defined as the economic value of the three categories of intangible assets of organizations including human resources, organizational capital, and social capital to collectively contribute to improving organizational performance (Choudhury, 2010). Thus the three components of intellectual capital that will provide significant influence on the performance of the organization as long as there is a linkage between each component

Seeing the results of the research mentioned above seem to look for the relationship between intellectual capital variable with performance variable.

Based on the description of causal relationships between variables above, this research paradigm can be seen in the following figure 2.1. :

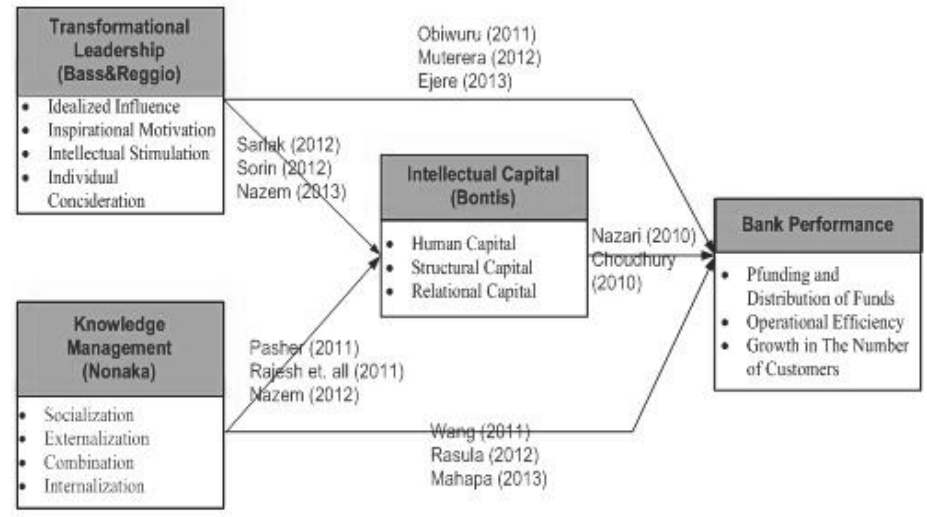

Figure 2.1. Research Model

\section{Methodology}

The research method used is descriptive survey method and explanatory survey method because this research is descriptive and verificative conducted through data collection in the field. The population is all branches $(\mathrm{KC})$ and subbranches (KCP) the state owned banks in West Java, measuring 609 branches, Mandiri 174 branches, BRI 296 branches, BNI 78, and BTN 61 branches. The number of bank branches / sub-branches that will be sample using Slovin formula $\left(n=\frac{N}{N^{2}+1}\right)$ and a proportional allocation formula $n_{i}=\frac{N_{i}}{N} \cdot n$, produced sample size of 20 branches and 171 sub branches. Techniques of data collection will be done by using three ways, namely field study through interviews, questionnaires; the study of literature; and interval data scoring (Sekaran, 2006). To test the validity of instument using correlation coefficient and reliability test using Cronbach Alpha coefficient formula. The hypothesis testing is done through Structural Equation Model (SEM) using LISREL software (Hair et. Al., 2006)

\section{Discussion}

This paper is a blend of concepts and theories. The concept used is very good. This paper submitted for seminar with the aim to finalize the accuracy of the concepts used. Field testing is needed to ensure that the concept or theory that is used can be applied in the branch office of state owned banks as a solution for poor performance, especially in terms of efficiency. The conclusion that can be drawn is Transformational Leadership and Knowledge Management influence on Intellectual Capital and Intellectual Capital affect the branch office of state owned banks Performance in West Java. 


\section{References}

Bass, B.M. (1990). From transactional to transformational leadership: Learning to share the vision. Organizational dynamics, 18 (3), 1931

Bass. B. M., \& Riggio, R.E, 2006. Transformational Leadership, 2nd Edition. New Jersey : Lawrence Erlbaum Associated Inc.

Becerra Irma, Fernandez, and Rajiv Sabherwal. 2010. Knowledege Mangement System and Process. New York : ME. Sharpe.

Bontis, Nick, Chua, W. and S. Richardson. (2000). Intellectual capital and business performance in Malaysian industries. Journal of Intellectual Capital, 1, 1, 85-100

and Fitz-enz, J. 2002. Intellectual Capital ROI: A Causal Map of Human CapitalAntecedents and Consequents. Journal of Intellectual Capital, 33, pp. 223-47.

Choudhury, Jyotirmayee. 2010. Performance Impact of Intellectual Capital: A Study of Indian it Sector. International Journal of Business and Management Vol. 5, No. 9; September 201072 ISSN 1833-3850 E-ISSN 1833-8119

Cocriș, V.; Andrieș, A. 2009. Managementul riscurilor și al performanțelor bancare, Wolters Kluwer Publishing.

Cocriș, V.; Chirleșan,D. 2007. Management bancar și analiza de risc în activitatea de creditare, lași. "Alexandru loan Cuza" University Publishing.

Daft. R. L. 2000. Organization Theory \& Design 7th ed. USA : Soth Western College Publishing Thomson Learning.

Edvinsson Leif, Sullivan Patrick.1996. Developing a model for managing IC. European Management Journal, Vol.14, № 4, p. 357.

Ejere, Emmanuel Iriemi and Ugochukwu David Abasilim. 2012. Impact of Transactional and Transformational Leadership Styles on Organisational Performance: Empirical Evidence from Nigeria. The Journal of Commerce, Vol. 5, No. 1 ISSN: 2218-8118, 22206043 Hailey College of Commerce, University of the Punjab, PAKISTAN

Gimenez, F. A. P. 2000. The Benefits of a Coherent Strategy for Innovation and Corporate Change: A Study Applying Miles and Snow's Model in the Context of Small Firms. Strategy and Innovation in Smes, 9(4), 235-244.

Gruian, C. 2010. Ce înţelegem prin performanţa companiei, The Scientific annals of Constantin Brâncuşi Târgu Mureş, Economic Series, No.4. p. 243-255.

Hadi, Abdul \& Wahab Al-Abrrow. 2014. Transformational Leadership and Organisational Performance in the Public Healthcare Sector: The Role of Organisational Learning and Intellectual Capital. Irish Journal of Management.

Hair, Black, Babin, Anderson, dan Tathan. 2006. Multivariate Data Analysis-Sixth Edition. Pearson Prentice Hall. New Jersey.

Hamon, T. T. (2003). Organizational effectiveness as explained by social structure in a faith-based business network organization. unpublished doctoral dissertation, Regent University, Virginia Beach, VA

Hernandez S. Robert \& O'Connor Stephen J. 2010. Strategic Human Resources Management in Health Services Organizations, third Edition. USA : Delmar Cengage Learning.

Lukman, Dendawijaya. 2009. Manajemen Perbankan. Ghalia Indonesia. Bandung

Mahapa, Mildred. 2013. Impact of Knowledge Management Strategies on OrganizationalPerformance in the Hospitality Industry of Zimbabwe. Public Administration Research; Vol. 2, No. 1; 2013 Published by Canadian Center of Science and Education

Muterera, J. 2012. Leadership Behaviours and Their Impact on Organizational Performance in Governmental Entities. International Journal of Sustainable Development. pp.19-24.

Nazari, Jamal Aldin. 2010. An Investigation of the Relationship between the Intellectual Capital Components and Firm's Financial Performance. A Thesis Submitted to The Faculty of Graduate Studies in Partial Fulfilment of The Requirements for The Degree of Doctor of Philosophy Haskayne School of Business Calgary. Alberta.

Nazem, Fattah. 2012. The Compilation of a Structural Model for Intellectual Capital Based on the Knowledge Management in Universities Department of Education. Roudehen Branch.Islamic Azad University, Roudehen, Iran

Nonaka I. \& Takeuchi H. 1995. The Knowledge Creation Campany: How Japanese Companies Create The Dynamic of Innovation. New York : Oxford University Press.

Obiwuru, T. C., Okwu, A. T, Akpa, V. O. \& Nwankwere, I. A. 2011. Effects of Leadership Style on Organizational Performance: A Survey of Selected Small Scale Enterprises in Ikosi-Ketu Council Development Area of Lagos State, Nigeria. Australian Journal of Business and Management Research. Vol.1. No. 7. pp 100-111.

Parnell, J. A. \& Wright, P. 1993. Generic Strategy and Performance: An Empirical Test F the Miles and Snow Typology. British Journal of Management, 4, 29-36.

Pasher Edna \& Ronen Tuvya. 2011. The Complete Guide to Knowledge Management : a Strategic Plan to Leverage your Campany's Intellectual Capital . USA : Wiley.

Rajesh, R., Pugazhendhi, S. and Ganesh, K. 2011. Towards taxonomy architecture of knowledge management for third party logistics service provider. Benchmarking: An International Journal, Vol. 18 No. 1, pp. $42-68$.

Ranjani R.P.C., Fernando J.M.R., Kumari P.W.N.A. 2011. The Implications of Intelellectual Capital on Banks Performance in Sri Lanka. International Journal on GSTF Business Review Vol. 1 No. 1

Rašula, Jelena ; Vesna Bosilj Vukšić; Mojca Indihar Štemb erg er. 2012. The Impact of Knowledge Management on Organizational Performance. Economic and Business Review.

Robbins Stephen P.2008. Perilaku Organisasi: Konsep, Kontroversi, Aplikasi.Terjemahan Hadyanan Pujaatmaka. Jakarta: PT Prenhallindo.

Ronald Maier. 2007. Knowledge management systems - information and communication technologies for knowledge management (3. ed.). Springer. 
Sarlak, Mohammad Ali , Moradgholi , Mahdi, Ghorbani Ali . 2012. Effect of transformational leadership on intellectual capital. African Journal of Business Management Vol.6 (27), pp. 7977-7986

Segev, E. 1987. Strategy, Strategy-Making and Performance in a Business Game. Strategic Management Journal, 8, 565-577.

Sekaran, U. 2006. Research Methods for Business, a Skill Building Approach. 4th ed.John Wiley \& Sons, Inc. NY.P 32. Terjemahan

Smith, K. G., Guthrie, J. P. \& Chen, M. 1989. Strategy, Size and Performance. Organizational Studies. 10, 63-81

Snow, C. C. \& Hrebiniak, L. G. 1983. Strategy, Distinctive Competence, and Organizational Performance. Administrative Science Quarterly, 25,307-335.

Sorin Anagnoste, Simona Agoston and Alina Mihaela Dima, Surakka, Jukka. 2012. Transformational Leadership and its Influence on Intellectual Capital in the Romanian Business Environment . Proceedingsof the 4th European Conference on Intellectual Capital Arcada University of Applied Sciences Helsinki Finland The Academy of Economic Studies, Bucharest, Romania

Statistik Perbankan Indonesia melalui www.bi.go.id

Stewart, A.T. 1997. Intellectual Capital : The New Wealth of Organization. New York : Bantam Doubleday Dell Publishing Group

Stewart, Thomas A. 1997. Intellectual Capital: The Wealth of New Organizations. London: Nicholas Brealey Publishing.

Sveiby, K. 1997. The New Organizational Wealth, San Franscisco.CA Berrett-Koehler Publishers.

Thomas, A. S. \& Ramaswamy, K. 1996. Matching Managers to Strategy: Further Tests of Miles and Snow Typology. British Journal Management, 7, 247- 261.

Verboncu,l; Zalman, M. 2005. Management şi performanţe. București, University Publishing.

Wang, W. 2011. Examining the use of knowledge management during issue management. Management Research Review, Vol. 34 No. 4 (forthcoming). 